\title{
PENGEMBANGAN MEDIA PEMBELAJARAN BERBASIS KAHOOT PADA MATERI RUANG LINGKUP BIOLOGI SMA/MA X
}

\author{
Nurbaetina*1, Evi Roviati $^{2}$ \\ ${ }^{1,2}$ Tadris Biologi, FITK IAIN Syekh Nurjati Cirebon; Jl. Perjuangan, Kecamatan \\ Kesambi, Kota Cirebon, Jawa Barat, 45132 \\ e-mail: *1nurbaetina31@gmail.com, ${ }^{2}$ evi1roviati@gmail.com
}

\begin{abstract}
ABSTRAK
Globalisasi dan teknologi mengalami perkembangan dengan pesat. Dunia pendidikan pun ikut merasakan perkembangan yang terjadi. Salah satunya memudahkan pendidik mengembangkan media pembelajaran berbasis kahoot terutama pada materi ruang lingkup biologi. Kahoot adalah salah satu alternatif media pembelajaran interaktif dengan menekankan gaya belajar yang melibatkan peran aktif partisipasi peserta didik. Penelitian ini bertujuan untuk pengembangan media pembelajaran berbasis kahoot pada materi ruang lingkup biologi SMA/MA X. Penelitian ini menggunakan metode penelitian dan pengembangan (R\&D) dengan model ADDIE dan menggunakan sampel 3 mahasiswa sebagai validator dan 10 peserta didik sebagai responden. Hasil penelitian menunjukan bahwa nilai validasi terhadap media pembelajaran kahoot layak untuk digunakan. Media pembelajaran kahoot mampu menarik perhatian peserta didik dan nilai rata-rata dari uji coba media kepada 10 peserta didik diperoleh 82 . Media pembelajaran kahoot dengan berbasis digital game based learning mampu menarik peserta didik dalam proses pembelajaran yang tidak membosankan. Hal ini dapat dilihat dari hasil uji coba media pada tabel 2 dan pada grafik 1 presepsi peserta didik terhadap media pembelajaran kahoot dengan digital game based learning.
\end{abstract}

Kata Kunci : Ruang lingkup biologi, Kahoot, Media Pembelajaran, Game Base Learning.

\begin{abstract}
ABSTRAK
Globalization and technology have developed rapidly. The world of education also feels the developments that are happening. One of them makes it easier for educators to develop kahoot-based learning media, especially in the scope of biology. Kahoot is an alternative interactive learning media by emphasizing learning styles that involve the active participation of students. This study aims to develop kahoot-based learning media in the biology scope of SMA / MA X. This study uses the research and development $(R \& D)$ method with the ADDIE model and uses a sample of 3 students as validators and 10 students as respondents. The results showed that the validation value of kahoot learning media was feasible to use. The kahoot learning media was able to attract the attention of students and the average score of the media trial for 10 students was 82. Kahoot learning media based on digital game-based learning were able to attract students in a learning process that was not boring. This can be seen from the results of media trials in table 2 and in graph 1 students' perceptions of kahoot learning media with digital game based learning.
\end{abstract}

Keywords: Biology scope, Kahoot, Learning Media, Game Base Learning. 


\section{PENDAHULUAN}

Globalisasi dan teknologi mengalami perkembangan dengan pesat (Darmawan, 2020). Perkembangan globalisasi dan teknologi membawa pengaruh besar terhadap perubahan disemua sektor kehidupan bahkan dunia pendidikan juga ikut merasakan dampak dari perkembangan globalisasi dan teknologi ini. Menurut Cahyadi (2019), peran teknologi dalam dunia pendidikan menjadi penting untuk mengimplementasikan pada proses pembelajaran yang mengarah kepada pemecahan persoalan belajar peserta didik.

Perkembangan ini dalam dunia pendidikan memudahkan pendidik mengakses berbagai informasi untuk sumber belajar ataupun mencari media untuk proses pembelajaran. Media pembelajaran adalah alat yang digunakan dalam proses pembelajaran dan bertujuan untuk memperjelas penyajian informasi, memperlancar proses pembelajaran, dan meningkatkan hasil belajar.

Menurut Titin dan Dara (2016), penggunaan media pembelajaran berfungsi untuk memperjelas penyajian pesan dan informasi suatu materi sehingga dapat memperlancar dan meningkatkan proses dan hasil belajar.

Materi ruang lingkup biologi adalah materi yang isinya mencakup tentang seluruh hal yang berhubungan dengan biologi (Titin dan Dara, 2016). Materi ruang lingkup biologi adalah ilmu yang mempelajari tentang seluruh kehidupan makhluk hidup, baik uniseluler maupun multiseluler. Objek kajian biologi mulai dari tingkatan makhluk hidup yang paling sederhana (sangat kecil) hingga tingkatan organisasi yang paling kompleks (terbesar).

Tingkat-tingkat organisasi biologis adalah tingkat biosfer, tingkat ekosistem, tingkat komunitas, tingkat populasi, tingkat organisme, tingkat organ dan sistem organ, tingkat jaringan, tingkat sel, tangkat organel, dan tingkat molekul (Campbell et al., 2010).

Ruang lingkup biologi memiliki cangkupan yang luas dan berkembang membentuk cabang ilmu biologi. Beberapa cabang ilmu biologi, diantaranya Anatomi, Botani, Ekologi, Embriologi, Entomologi, Evolusi, Fisiologi, Genetika, Histologi, Mikrobiologi, Taksonomi, dan Zoology.

Objek pembelajaran ruang lingkup biologi tidak semua dapat diamati secara langsung. Oleh karena itu, diperlukan media pembelajaran untuk membantu memperjelas pesan pembelajaran sehingga persepsi peserta didik dengan objek yang sebenarnya menjadi sama. Pembelajaran ruang lingkup biologi juga akan lebih menarik, interaktif, dan tidak membosankan dapat dengan menggunakan digital game base learning.

Digital Game Base Learning merupakan metode penggabungan konten pendidikan ke dalam game. Digital Game Base Learning memanfaatkan pembelajaran melalui pola belajar dan bermain dengan memanfaatkan teknologi (Putri dan Muzakki, 2019). Salah satu platform yang dapat digunakan untuk Game-based Learning adalalah Kahoot.

Kahoot dapat digunakan untuk mengembangkan teknologi pendidikan berbasis digital game based learning untuk diintegrasikan didalam kelas ataupun secara online dan dapat mengakses dengan bantuan berbagai perangkat, seperti laptop, smartphone, tablet, dan proyektor. Penggunaan kahoot memerlukan koneksi. Dalam media kahoot terdapat dua macam cara bermain, yaitu classic yang berarti peserta didik bermain secara individu dan team mode yang berarti peserta didik bermain secara kelompok.

Kahoot adalah salah satu alternatif media pembelajaran interaktif dengan menekankan gaya belajar yang melibatkan peran aktif partisipasi peserta didik (Ramadhan et al., 2020). Kahoot adalah platform berbasis game online gratis yang memungkinkan pengguna untuk menyusun penilaian pilihan ganda yang berubah menjadi permainan interaktif bagi pesert didik (Jones et al., 2019). Kahoot merupakan salah satu game dengan konsep unik yang dikembangkan dari Lecture Quiz Proyek Penelitian (Lin et al., 2018). Kahoot dapat membantu aktifitas evaluasi pembelajaran menjadi lebih 
menarik, interaktif, kondusif dan mudah untuk memonitoring hasil belajar peserta didik. Fitur yang dimiliki platform kahoot, yaitu kuis, diskusi, game, dan survay (Putri dan Muzakki, 2019).

Media kahoot memiliki beberapa keunggulan dalam proses pembelajaran, antara lain soal-soal yang disajikan dalam media kahoot memiliki alokasi waktu yang terbatas sehingga dapat melatih peserta didik berpikir secara cepat dan tepat serta memungkinkan pendidik untuk membuat kuis, diskusi, pertanyaan dengan memasukkan berbagai elemen seperti video, gambar, maupun teks

Hasil penelitian Titin dan Dara (2016), media pembelajaran berupa film documenter dinyatakan layak digunakan sebagai media pembelajaran pada materi ruang lingkup biologi, karena mampu meningkatkan hasil belajar dan efektif. Hasil penelitian Sabran dan Sabara (2014), mengatakan bahwa penggunaan media baru merupakan pemanfaatan yang adaptif karena mampu memberikan metode dan pengalaman belajar mengajar baru. Dengan demikian, artikel ini bertujuan untuk pengembangan media pembelajaran berbasis kahoot pada materi ruang lingkup biologi SMA/MA X.

\section{METODE}

Metode penelitian yang digunakan adalah metode penelitian dan pengembangan atau Research and Development (R\&D). Penelitian ini berfokus pada pengembangan media pembelajaran berbasis Kahoot pada materi Ruang Lingkup Biologi. Penelitian dilakukan pada bulan November 2020 dengan sampel penelitian 3 orang mahasiswa sebagai validator dan 10 orang peserta didik sebagai responden. Penelitian ini diharapkan dapat menghadirkan sebuah media pembelajaran yang interaktif, menarik, dan meningkatkan hasil belajar peserta didik.

Prosedur penelitian yang digunakan mengacu pada model pengembangan ADDIE, yang terdiri dari 5 tahap yakni Analysis, Desain, Development or
Production, Implementation or Delivery, dan Evaluations. Model ADDIE adalah salah satu desain pengembangan bahan ajar yang sering digunakan dan proses pembelajaran bersifat interaktif dengan tahapan-tahapan dasar pembelajaran yang efektif, dinamis, dan efisien.

\section{HASIL DAN PEMBAHASAN}

Media yang dikembangkan dalam penelitian ini adalah media pembelajaran interaktif berbasis kahoot untuk materi ruang lingkup biologi kelas $\mathrm{X}$.

Media pembelajaran adalah salah satu alat bantu untuk mengajar bagi seorang pendidik untuk menyampaikan materi pembelajaran, meningkatkan kreatifitas peserta didik, dan meningkatkan perhatian peserta didik dalam proses pembelajaran. Dengan menggunkan media peserta didik akan termotivasi untuk belajar, mendorong siswa berbicara, dan berimajinasi yang semakin terangsang dengan penggunaan media pembelajaran tersebut (Tafanao, 2018).

Media yang dikembangkan pada penelitian ini yakni kahoot di dalamnya terdapat berbagai unsur media pembelajaran yang dikombinasikan yaitu gambar, video, dan teks. Dengan mengombinasikan gambar, video, dan teks peserta didik dapat mendengar dan melihat secara langsung objek-objek yang dipelajari pada materi ruang lingkup biologi. Selain itu, menampilkan video dan gambar terkait objek dan permasalah biologi dapat membantu peserta didik mengamati secara langsung dan mudah mengingatnya.

Objek biologi contohnya seperti objek yang dipelajari pada cabang-cabang ilmu biologi, salah satunya yaitu ornitologi yang merupakan cabang ilmu biologi yang mempelajari tentang burung. Sedangkan permasalahan biologi pada tingkatan organisasi kehidupan, contohnya kematian ikan secara massal karena air keracunan yang dapat disebabkan oleh limbah. Penanganan masalahan ini dapat melibatkan objek biologi dengan pendekatan cabang ilmu dan tingkat 
organisasi biologi yaitu toksikologi populasi.

Media yang telah dibuat akan diuji coba kepada 10 orang peserta didik sebagai responden terhadap media tersebut dengan cara mengakses internet dan di bantuan oleh berbagai perangkat, seperti laptop, smartphone, tablet, dan proyektor.

Uji coba media pembelajaran kahoot dilakukan setelah media divalidasi oleh validator. Hasil validasi media yang telah dilakukan validator dapat dilihat pada tabel 1 .

\section{Tabel 1. Penilaian Validasi Media}

\begin{tabular}{|c|c|c|}
\hline$\underline{\text { Kriteria penilaian }}$ & $\sum \mathrm{VVY}$ & IVT \\
\hline $\begin{array}{l}\text { Kompetensi dasar }(\mathrm{KD}) \\
\text { dan indikator pencapaian } \\
\text { kompetensi tercantum }\end{array}$ & 3 & 0 \\
\hline $\begin{array}{l}\text { Tujuan pembelajaran telah } \\
\text { sesuai dengan indikator } \\
\text { pencapaian }\end{array}$ & 3 & 0 \\
\hline $\begin{array}{l}\text { Menentukan langkah- } \\
\text { langkah pembelajaran }\end{array}$ & 3 & 0 \\
\hline $\begin{array}{c}\text { Bahasa yang digunakan } \\
\text { baik dan benar } \\
\text { Aspek materi }\end{array}$ & 2 & 1 \\
\hline $\begin{array}{c}\text { Rumusan soal sesuai dengar } \\
\text { indikator pencapaian }\end{array}$ & 3 & \\
\hline $\begin{array}{l}\text { Batasan jawaban atau } \\
\text { ruang lingkup yang diuji } \\
\text { sudah jelas }\end{array}$ & 2 & 1 \\
\hline $\begin{array}{l}\text { Isi materi sesuai dengan } \\
\text { jenjang seko }\end{array}$ & 3 & \\
\hline Jumlah & $\underline{19}$ & $\underline{2}$ \\
\hline$\underline{\text { Kesimpulan }}$ & Layak digı & zunakan \\
\hline
\end{tabular}

Keterangan

$\Sigma$ VY : Jumlah validator yang menjawab Ya

$\Sigma$ VT : Jumlah validator yang menjawab Tidak

Berdasarkan hasil validasi media pembelajaran kahoot yang telah dilakukan oleh 3 orang mahasiswa sebagai validator dapat diketahui bahwa media tersebut layak digunakan untuk media pembelajaran terutama pada materi ruang lingkup biologi.

Hal ini dikarenakan nilai pada kriteria penilaian media memperoleh nilai tinggi sehingga media layak untuk digunakan dan lanjut ke tahap uji coba media kepada peserta didik.

Tabel 2. Perolehan Uji Coba Media

\begin{tabular}{ccccc}
\hline Nilai & fi & Mean & Variance & Std. \\
47 & 1 & 82 & 227,2 & 15,1 \\
67 & 1 & & & \\
73 & 1 & & & \\
80 & 1 & & & \\
87 & 2 & & & \\
93 & 3 & & & \\
100 & & & & \\
\hline
\end{tabular}


Berdasarkan tabel 2 dapat diketahui bahwa nilai rata-rata atau mean dari hasil uji coba pada 10 peserta didik, didapatkan nilai sebesar 82. Media pembelajaran dengan menggunakan kahoot mampu menarik perhatian peserta didik dan peserta didik tidak merasa bosan. Hal ini dapat dilihat dari respon peserta didik yang dapat dilihat pada gambar 1.

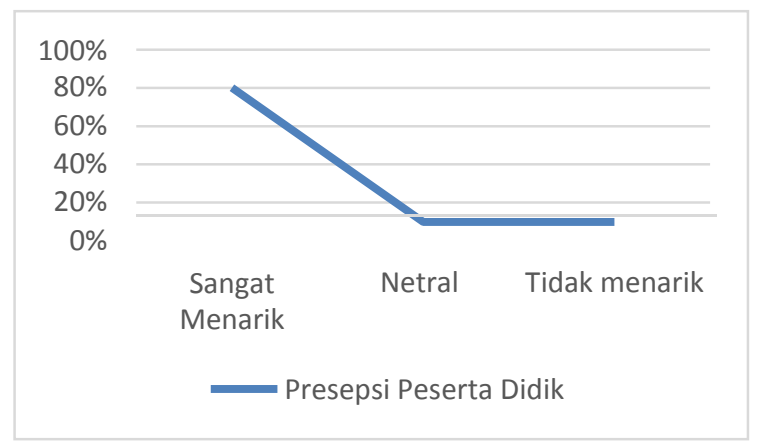

\section{Gambar 1. Respon Peserta Didik}

Persepsi peserta didik dengan media pembelajaran kahoot berbasis game based learning dapat dilihat pada grafik 1 . Berdasarkan dari grafik 1 presepsi peserta didik sebesar $80 \%$ mengatakan bahwa media yang digunakan tersebut sangat menarik untuk diaplikasikan dan digunakan dalam proses pembelajaran sehingga permasalahan kebosana ndan ketidaktertarikan dalam belajar dapat diatasi.

Menurut Plump dan Larosa (2017), platform kahoot efektif untuk digunakan sebagai media pembelajaran karena kemampuannya dapat mendorong dan memperkuat pembelajaran. Kahoot dapat digunakan sebagai alat kognitif, dapat menjadikan peserta didik untuk lebih terlibat dan berpikir lebih mendalam tentang subjek yang diteliti dan memfasilitasi membangunan pengetahuan dan refleksi peserta didik (Darmawan, 2020).

Hasil penelitian Darmawan (2019), mengatakan bahwa penggunaan media kahoot namun bukan pada materi ruang lingkup biologi, melainkan pada materi perubahan lingkungan memberikan hasil yang signifikan terhadap hasil belajar biologi siswa SMA Negeri 1 Muncar dengan ratarata nilai post test kelas eksperimen dengan menggunakan kahoot sebesar 86,35 sedangkan rata-rata di kelas kontrol sebesar 80,13 .

\section{KESIMPULAN}

Media pembelajaran kahoot dengan berbasis digital game based learning mampu menarik peserta didik dalam proses pembelajaran yang tidak membosankan. Hal ini dapat dilihat dari hasil uji coba media pada tabel 2 dan pada grafik 1 presepsi peserta didik terhadap media pembelajaran kahoot dengan digital game based learning. Penggunaan kahoot pada materi ruang lingkup biologi berdasarkan hasil dari uji coba pada peserta didik, rata- rata niali yang diperolah sebesar 82 dengan nilai standar deviation 15,1 .

Kehadiran kahoot memudahkan pendidik dalam mengembangkan teknologi pendidikan berbasis digital game based learning untuk diintegrasikan di dalam kelas maupun secara online (Putri dan Muzakki, 2019).

\section{DAFTAR PUSTAKA}

Cahyadi, R.A.H. (2019). Pengembangan Bahan Ajar Berbasis ADDIE Model. Halaqa: Islamic Education Journal. Vol. 3. No. 1, pp 35-43.

Campbell, A.N, Reece, B.J, dan Mictchel, G.L. (2010). Biologi Edisi 8 Jilid 1. Jakarta: Erlangga. 
Darmawan, A. (2020). Pengaruh Penggunaan Kahoot Terhadap Hasil Belajar Materi Ruang Lingkup Biologi Di Sma Negeri 1 Muncar. Jurnal Edukasi dan Teknologi Pembelajaran. Vol. 1. No. 2, pp 91-99.

Darmawan, A. (2019). Pengaruh Penggunaan Kahoot Terhadap Hasil Belajar Biologi Materi Perubahan Lingkungan. Prosiding Seminar Internasional Bagi Guru dan Tenaga Kependidikan IPA. Bandung.

Jones, S.M., Katyal, P., Xie, X., Nicolas, M.P., Leung, E.M., Noland, D.M., and Montclare, J.K. (2019). A 'KAHOOT!' Approach: The Effectiveness of GameBased Learning for an Advanced Placement Biology Class. Simulation \& Gaming. Vol. 50. Vol. 6, pp 832847.

Lin, D.T.A., Ganapathy, M., and Kaur, M. (2018). Kahoot! It: Gamification In Higher Education, Pertanika. Journal Soc. Sci. Humanit. Vol. 26. No. 1, pp 565-582.

Ramadhana, M.F., Ahdhiantob, E., Perdanac, R., dan Baehak, F. (2020). Effectiveness Of Use Of Kahoot As A Media In Learning In The Scope Of Biological Scope. Journal of Xi'an University of Architecture \&
Technology. Vol. 12. No. 7, pp 587- 594.

Sabran dan Sabara, E. (2014). Keefektifan Google Classroom Sebagai Media Pembelajaran. Prosiding Seminar Nasional Lembaga Penelitian Universitas Negeri Makassar Pada Diseminasi Hasil Penelitian Melalui Optimalisasi Sinta Dan Hak Kekayaan Intelektual. Makassar: Universitas Negeri Makassar.

Plump, C.M. and Larosa. (2017). Using Kahoot! in the Classroom to Create Engagement and Active Learning: A Game-Based Technology Solution for eLearning Novices. Management Teaching Review. Vol. 2. No. 2, pp151-158.

Tafanoa, T. (2018). Peranan Media Pembelajaran Dalam Meningkatkan Minat Belajar Mahasiswa. Jurnal Komunikasi Pendidikan. Vol. 2. No. 2, pp 103114.

Titin dan Dara, E.N. (2016). Penyusunan Perangkat Pembelajaran Pada Materi Ruang Lingkup Biologi Kelas X SMA. Jurnal Pendidikan Matematika dan IPA. Vol. 7. No. 1, pp 45-56. 